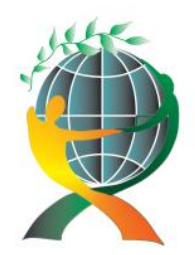

\author{
(online) $=$ ISSN $2285-3642$ \\ ISSN-L = $2285-3642$ \\ Journal of Economic Development, Environment and People \\ Volume 1, Issue 2, 2012
}

URL: http://jedep.spiruharet.ro

e-mail: office jedep@spiruharet.ro

\title{
Adapting of Economic Development to Climate Change
}

\author{
Sandra Zajmi MSc \\ Požeška 12a, 11000 Beograd \\ zajmi@open.telekom.rs
}

\begin{abstract}
Climate change is the most complex challenge that humankind has had to face in recent times. With each successive generation, redressing the imbalance will be more difficult. Diverse and complex requirements of maintaining life on Earth, collectively called the environment, can be caused both by natural, geophysical factors, and anthropogenic or social factors.

There is a lot of evidence that the economic activity of mankind is a major anthropogenic factor in current turmoil of the environment on Earth. Since the middle of the nineteenth century, the anthropogenic impacts on the environment are becoming increasingly important, and undoubtedly dominate. Of all forms of economic activity the greatest impact have the activities related to energy production and use in various sectors. The link between environmental conditions and economic activities has become the subject of separate scientific disciplines that are dynamically developing in the second half of the twentieth century.

Economic growth of the economies, especially of developed countries, in seventies and eighties of the twentieth century, drew attention to the growing international economic, political and ecological interdependence, particulary in terms of its ecological outcome. The future economic growth of all countries on the planet is becoming a global problem.

In this context, more attention must be paid to the relationship between population, resources, and environmental outcomes on one side, and long-term sustainable economic development on the other side. In the recent time there have been noticeable the increasing number of problems that are becoming global: economic, social and energy problems, and contain ecological basis. Human decisions and activities are dependent on ethics and view of the world, and this view depends on the culture, tradition, achieved level of development and so on.

Therefore, it is necessary to adjust economic development to climate change, where a great importance plays cooperation between the public and private sector.
\end{abstract}

Keywords: Economic development, Climate change, Environment, Economic growth, Globalization.

JEL Codes: Q54, Q56, Q44, F4 


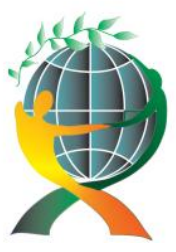

\author{
(online) $=$ ISSN $2285-3642$ \\ ISSN-L = $2285-3642$ \\ Journal of Economic Development, Environment and People \\ Volume 1, Issue 2, 2012 \\ URL: http://jedep.spiruharet.ro \\ e-mail: office jedep@spiruharet.ro
}

\section{Introduction}

“Missed opportunity never returns" ${ }^{1}$

There is almost no man in the world who has not heard for climate change and its meaning, at least in some extent. The point is the fact that gases generated in industrial production and greenhouse gas emissions, lead to increase of climate temperature on Earth which in the future can have catastrophic consequences. Nevertheless, the vast majority of people do little, or does nothing to change their habits in everyday life, even though they are a source of danger that threaten our climate changes.

One can not say that we are not aware of the occurrence of climate change. On the contrary, many books have been written related to climate change and their potential consequences. For at least twentyfive years or more, authors and others are expressing great concern about the warming of Earth's atmosphere, but without significant results. In recent years, the issue erupted in the foreground of discussions and debates and not only across countries but across the world. However, as humanity, we are just beginning to take necessary measures against the dangers which we face our next generation. However, global warming, due to its importance and because it is mainly related to the future, is the problem that is different from all others. It is a danger that seems abstract and elusive, despite the potential destructiveness of its consequences.

Politicians are becoming aware of the importance of this problem and the urgency to solve it and therefore, many countries have recently started to implement an ambitious policy on climate change. In recent years an important step was initiated: Most political leaders became aware of the risks that climate change means and the need to respond to them. It is only the first step-the introduction of the topic in the realm of politics and economics. The second step would have to mean that it becomes part of our institutions and everyday concerns of citizens, and in order to do that, much more needs to be done. The international community has been launched, at least in principle. In order to reduce worldwide emissions of greenhouse gases, the United Nations are organizing talks on limiting global warming. They started in Rio 1992, continued in Kyoto 1997 and after that in Bali in 2007. Discussions are still been held, but without significant and concrete results.

\footnotetext{
${ }^{1}$ Slović Dragoslav, Epigrams, Fineks, Belgrade, 2011.
} 


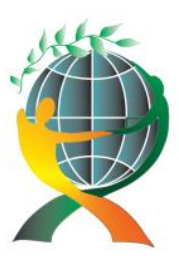

\author{
(online) $=$ ISSN $2285-3642$ \\ ISSN-L = $2285-3642$ \\ Journal of Economic Development, Environment and People \\ Volume 1, Issue 2, 2012 \\ URL: http://jedep.spiruharet.ro \\ e-mail: office jedep@spiruharet.ro
}

Emissions markets can function only with a fixed maximum price of carbon, and such decision, and its implementation in practice, is a matter of politics and economics. Crucial impact in reducing emissions of greenhouse gases will have the technological advances, but it has to be conducted with support from the government. The only existing large supranational Community, European Union, is highly dependent on decisions made by its member states, because EU has only limited authority over them.

The role of markets in mitigating climate change is more than simply controlling the emissions. Market forces, in many areas, can achieve what no one else can. In general, when the price of ecological goods can be determined without compromising other values, it should be done, because the competition will contribute to greater efficiency in every exchange of the goods. Environmental costs incurred as a result of economic processes, often lead to what economists call "independent external influences"- are not borne by those who caused them. Therefore, the objective of national policy should be to ensure that these costs, whenever possible, be an internal matter, namely the market's matter.

Countries which are the vanguards in creating policies and economics related to climate change, and developed countries need to be those, may face the problem of competition. Their economy may fall into difficulties, because they must be exposed to competitive goods, that somewhere else, where there are no environmental taxes and regulatory restrictions, can be produced more cheaply. A number of business units and groups have used this reason for the slow response to the initiative for the introduction of measures to mitigate climate change.

Finally, there is a number of important issues about the technology. Key importance, in solving the problem of climate change, are investments in renewable energy. But these sources will not occur spontaneously, or only under the influence of market forces. To withstand the competition of fossil fuels, they must have a financial support of the government, and government must protect these investments from the impact of inevitable changes in prices of oil and natural gas. Technological changes may be predicted only in a limited extent.

Creating a policy on climate change requires new ideas, and one of which refers to the guarantee government. "When it comes to climate change, countries must provide, facilitate, encourage and support the diversity of social groups that drive the development of such policies. But it can not be limited to providing, as it must to ensure achievement of concrete results-especially the progressive reduction 


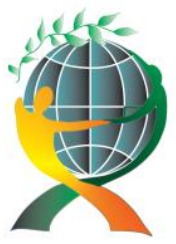

\author{
(online) $=$ ISSN $2285-3642$ \\ ISSN-L = $2285-3642$ \\ Journal of Economic Development, Environment and People \\ Volume 1, Issue 2, 2012 \\ URL: http://jedep.spiruharet.ro \\ e-mail: office jedep@spiruharet.ro
}

of emissions. Government guarantee is a government that is able to achieve such results, on which may rely not only its citizens but also leaders of other countries." ${ }^{2}$

\title{
2. The Politics of Adjustments
}

Borrowed from evolutionary biology, the term "adjustment" is widely used in texts on climate change. In some ways it is misleading, because it means responding to the consequences of climate change when they occur. But just as it is the case in efforts to limit global warming, the adjustment has to come onward and it must have a preventive character.

For adjustment is said to be "exposed to ridicule and miserable cousin of emission reductions". 3 Among the supporters of environmental adjustments, debates were at one time a taboo in fear that they could adversely affect on efforts to mitigate climate changes. Undoubtedly, however, is that the times have changed. In Bali, the same discussions were held related to adjustments as much as reductions.

Problems related to adjustments to climate change are in some way even more complex than those relating to mitigation. Because, if we are to be prepared to adjust before the climate change really occurs, or while they are still at an early stage, we need to determine what will be the consequences of global warming in many areas in which they will affect. It is important to determine the activities of adjustment policies, because they can be helpful in determining the direction of our effort. There is a difference between the subsequent adjustments and adjustments to possible future developments. Adjustments to possible future developments are often referred to as proactive adjustments (PA). ${ }^{4}$ As part of our present knowledge - and the available resources - PA should be at the heart of all our reflections about adjustments, although subsequent adjustments are certainly going to be necessary.

The essence of the PA is in diagnosis and the ensurance of sensitive areas and spots. Sensitive area is a risk- the risk of compromising some important activities, lifestyle or resources. Sensitivity is obviously the economic and social concept and it is not reffered only to the physical environment. When we talk about it, we must consider also its opposite side, resistance. Resistance is defined as the ability to adapt, the

\footnotetext{
${ }^{2}$ Giddens Anthony, The Politics of Climate Change, Polity Press Ltd, Cambridge, 2009, page 16.

${ }^{3}$ European Commision: Adapting to Climate Change in Europe, Commission of the European Communities, Brussels 2007.

${ }^{4}$ Giddens Anthony, The Politics of Climate Change, Polity Press Ltd, Cambridge, 2009, page 197.
} 


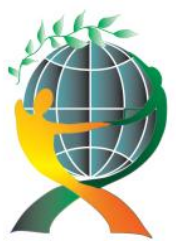

\author{
(online) $=$ ISSN $2285-3642$ \\ ISSN-L = $2285-3642$ \\ Journal of Economic Development, Environment and People \\ Volume 1, Issue 2, 2012 \\ URL: http://jedep.spiruharet.ro \\ e-mail: office jedep@spiruharet.ro
}

ability not only to non withdrawal to external changes and turns but also, whenever possible, activity and positive reaction to them. This may be characteristic of the physical environment, individuals or a group. The first case concerns the ability to withstand the environment created by changes of various kinds. It, for example, may take the form of retaining the existing embankments, or the timely construction of new ones, which serve as a defense against expected flooding. The second case relates to the individual's character traits - his ability to cope with adverse circumstances and to overcome them. As for the group, this trait refers to factors such as the ability of community members to work together, not divided and individually, and if necessary, modify and even reverse the current way of life. For example, small farmers who grow more crops will be more resilient than those who cultivate only one crop and depend on it.

Political and economic convergence are equally important for climate change adjustment policies as well as the way of their policy mitigatation - it will definitely affect how people will accept the proposed measures of all kinds. What is present all around is very limited effectiveness of policy of intimidation and provoking anxiety. The "polluter pays" principle is important as in the case of mitigation, both within individual countries and their mutual relationship. Rich countries must take much of the responsibility to adapt, at least when it comes to developing countries, just as they have to make efforts in limiting the development of global warming. Developing countries are much more vulnerable to the effects of climate change from the industrial developed countries, partly because many of them are in areas with unstable climate, and partly from the reason that they do not have the resources which are to be provided and ensured by already developed countries.

As in the case of the mitigation of climate change, but also in the making of policy and its implementation, the leading role must have the government. In order to support the process of adjustments, the government must encourage innovation and creativity in various fields of business and society. Involvement of citizens is required, and the rights and obligations must be allocated to different levels of management. A significant political problem is the fact that the financing of adjustment projects will inevitably be competitive investments necessary to mitigate climate change.

What the country needs to do in terms of adapting will depend to a large extent on its climate and geographical position. The U.S. has one of the most unstable climates in the world, extreme forms of its expression will become more stronger and more frequent. In countries with moderate climates such as Northern European countries, climate change may initially have some positive consequences. 


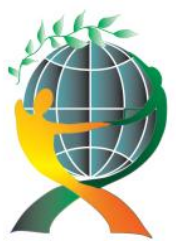

\author{
(online) $=$ ISSN $2285-3642$ \\ ISSN-L = $2285-3642$ \\ Journal of Economic Development, Environment and People \\ Volume 1, Issue 2, 2012 \\ URL: http://jedep.spiruharet.ro \\ e-mail: office jedep@spiruharet.ro
}

The first task in the adjustment policies for each country is to make a thorough review of vulnerabilities on the local and national level. Adjustments can contribute to innovations in the same way as mitigation strategies. At least a part of such changes would be beneficial per se, regardless of climatic events-such as greater efforts in savings of water, improved weather forecasting systems and planting crops resistant enough to succeed in adverse conditions. ${ }^{5}$

Adjustments are bringing us back to the question of planning, because it implies systematic thinking in advance. It should be understood not only as the search for vulnerabilities and its repair, but also as a result of the research of indirect potential mitigation strategies.

\title{
3. Emissions Market
}

The creation of emissions markets was made in Kyoto, but, like all forms of policies on climate change, it was influenced and affected by political and economic interests. The European Commission had initially planned to impose tax on emissions in all member states within its programs related to climate change. This has failed from a known cause-it can not overcome the opposing views of member states in relation to taxation.

Creating a market which would restrict environmental pollution, originates from the United States, where, at first, such markets were relatively successfully used to control emissions of sulfur dioxide. ${ }^{6}$ These emissions, which come from coal-fired power plants, were the main cause of "acid rains". But, instead of just reducing the quantity of sulfur dioxide, the creation of market with authorizations for its emissions has been made. The original proposal by Robert Stavins, the main author of the plan, consisted of authorizations which are than sold at auction shows to creators of emissions and thus establish their market value. But, it has been blocked in the Congress. Its adoption would mean that companies, whose products are subject of the consumption, had to pay large sum of money for such authorizations, which would be poured in the treasury of the federal government. ${ }^{7}$ Despite the shortcomings, the plan, in practice, led to a significant reduction in emissions, and with much less total cost than the industry representatives argued, who opposed the plan. The resulting market forces have contributed to the rapid creation of effective technological innovations in key industrial areas.

\footnotetext{
${ }^{5}$ Prins Gwyn, Raynor Steve, The Wrong Trousers, James Martin Institute, Oxford 2007, page 33-34.

${ }^{6}$ See: MacKenzie Donald, Making Things the Same, School of Social and Political Studies, Edinburgh 2008; and article „Constructing Emissions Markets“ in the book Material Markets, Oxford University Press, Oxford 2009 , chapter 7.

${ }^{7}$ Ellerman Denny et al., Markets for Clean Air, Cambridge University Press, Cambridge 2000.
} 


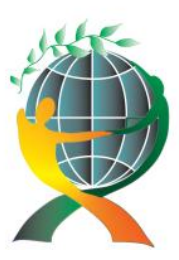

\author{
(online) $=$ ISSN $2285-3642$ \\ ISSN-L = $2285-3642$ \\ Journal of Economic Development, Environment and People \\ Volume 1, Issue 2, 2012 \\ URL: http://jedep.spiruharet.ro \\ e-mail: office jedep@spiruharet.ro
}

The preliminary plan for a possible international emissions market was made in Kyoto. It was agreed that industrialized countries can sell to each other "emissions reduction units", and that they can trade with developing countries and also that it can be take into account in terms of achieving their emission reduction quotas. EU system for emissions trading began operating in early 2005. It included about half the $\mathrm{CO}_{2}$ emissions in the EU-ones from the continuous production of energy, especially electricity, and from some countries with high energy consumption. It is not related to other gases that cause greenhouse effect. The goal was the creation of an open market with a single price for carbon emissions. However, a system that was introduced, was giving member states the right to determine their own national emissions quotas. The consequence of previously mentioned was oversized authorizations, because it was in the interest of all member states to provide themselves as much as possible favorable terms or at least some maneuver possibilities.

The European Commission stated that Phase 1 of the EU system for trading gas emissions was "phase of getting the experience" and that it will find a way to implement stronger market capitalization, in the process of market development. In order to prepare for phase 2, the national authorizing programs will be much more strict than it was reviewed before. More than $60 \%$ of authorizations will be sold at auction and it will, in addition to $\mathrm{CO}_{2}$, include other gases that cause greenhouse effect. ${ }^{8}$ The Commission intends, after 2012, to include in the system maritime transport and forestry. Unlike most of the voluntary emissions markets, it is based on authorizations rather than on projects-in other words, it is mutually determined by market capitalization.

When it comes to cash flow, in the period 2003-2008, market emissions are progressing rapidly. Data from Directorate for funding gas emission reduction of the World Bank, suggested that under such projects in 2008, enabled the exchange in the value of 337 metrictons of carbon dioxide, more than double compared to the previous year, in which was recorded an increase of that trade by $40 \%$, in comparison to year before. Will this tendency maintain under unfavorable conditions of global economic situation, which means less confidence in the markets, is a matter of assumption. Markets for gas emissions trading will certainly exist, although at this point, it can not be said how much emissions trading system-which is by far the most important one-in its modified form, will be effective.

As past experience, with the system for trading gas emissions shows, it will not be easy to estimate their contribution in restriction of these emissions, even though this limitation is their primary reason

${ }^{8}$ Giddens Anthony, The Politics of Climate Change, Polity Press Ltd, Cambridge, 2009, page 239. 


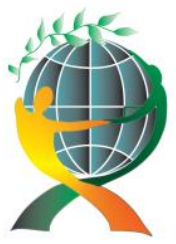

\author{
(online) $=$ ISSN $2285-3642$ \\ ISSN-L = $2285-3642$ \\ Journal of Economic Development, Environment and People \\ Volume 1, Issue 2, 2012 \\ URL: http://jedep.spiruharet.ro \\ e-mail: office jedep@spiruharet.ro
}

for existence. The leading author of Stern's review, recently proposed a "new global deal on climate change." ${ }^{9}$ Stern wants to contribute to negotiations on global agreement for the period after 2012, with the intention of reducing the concentration of gases causing the greenhouse effect, to 450 and $500 \mathrm{ppm} \mathrm{CO} \mathrm{CO}_{2} \mathrm{e}$. Given the already existing amount of these gases in the atmosphere, he says, that goal is very difficult to achieve, and no large country or group of countries, should lag behind in achieving the required reduction in emissions. "Each country must fulfill its obligations ... When you determine the basic parameters, governments around the world must commit to implement real concerted measures."10

Gas emissions trading will enable achievement of global goals in the most efficient and economical way, but the markets will have to be carefully planned and used in practice, because wrong measures can lead to their activities in the wrong direction, false incentives and increasing of protectionism. Stern predicts that by 2020, worldwide, will exist a system of market capitalization and gas emission trading that would include all industrial countries and wealthier developing countries.

The financial crisis shows that the international markets must operate more efficiently in the economic terms, and it takes time.

\title{
4. Tax Emissions
}

Systems of taxation will have an important role in stimulating innovation and, to some extent, in their guiding. Taxes are one of the main tools of governmental policy and in efforts to reduce emissions, they will certainly be of great importance. In the discussion of those who support emissions trading, and those who prefer its taxation, we consider the latter option is more appropriate, although the two strategies can be applied simultaneously.

There are two types of taxes which has the immediate cause of greenhouse gases: those whose funds are, in part or in whole, used to protect the environment, and those, whose aim is to comply people's behavior with the objectives regarding climate change. For example, taxes whose funds are invested in the development of renewable technologies can be included in the first category. Other taxes can serve as an incentive or as a punishment.

\footnotetext{
${ }^{9}$ Stern Nicholas, „Key Elements of a Global Deal on Climate Change“, 2008. Available on LSE web site.

${ }^{10}$ Ibid., page 10
} 


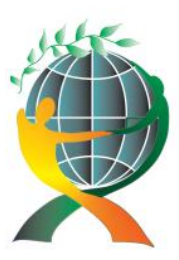

\author{
(online) $=$ ISSN $2285-3642$ \\ ISSN-L = $2285-3642$ \\ Journal of Economic Development, Environment and People \\ Volume 1, Issue 2, 2012 \\ URL: http://jedep.spiruharet.ro \\ e-mail: office jedep@spiruharet.ro
}

From an economic point of view, the purpose of taxing emissions is elimination of external influences, when it comes to environmental protection, to determine how much they really cost, including future generations. As in many other policy areas related to climate change, it is easy to present the principle, but it is often difficult to implement it in practice. For example, the cost of food production in the modern agriculture, which uses artificial fertilizers and pesticides do not include their adverse effects on arable land. They also do not include any emissions produced by transportation of food to all parts of the world. It is not easy to find the right price, and that goes for many other areas, having in mind the complexity of modern manufacturing processes. These taxes should contribute to energy conservation and use of innovations at the beginning of the production cycle and thus to reduce the need for subsequent interventions and recycling. Concerning the de novo emissions, tax should be capable of being trade for. In other words, citizens should have the opportunity to exchange tax in other areas. Such strategy can sometimes lead to "double win"- to limit pollution and at the same time benefits of other types. ${ }^{11}$

The widespread assertion is that, to the possible extent, taxation should include the "bad" (source emissions), not "good" (such as employees, in the form of income tax). ${ }^{12}$ This is in accordance with the "polluter pays" principle. However, it should be noted, that this is not black and white situation, as one might think, because we want to tax and to contribute to the active engagement of "good" source emissions in solving the problem of climate change-such as investment in renewable technologies. Taxation of "bad" means that they will rapidly replace the "good" ones, to the extent that taxation can contribute to social and economic changes, hence the revenues from these sources will inevitably decline, even if taxation take the form of tax incentives. Therefore, we must bear in mind the overall tax system, because everywhere will need to be introduced compensatory changes.

In many countries it has been thoroughly discussed about the possibilities of immediate tax exchange. Thus, an analysis in the United States showed an exchange tax of fifteen dollars per metric ton of greenhouse gases to reduce the federal income tax on earnings of employees on first 3,660 dollars of earnings of employees. ${ }^{13}$

How potentially regressive impact of taxing emissions raises concerns of many, it should be considered some of the proposed strategies for its counteract. In a survey conducted in the UK, Rowntree

\footnotetext{
${ }^{11}$ Giddens Anthony, The Politics of Climate Change, Polity Press Ltd, Cambridge, 2009, page 182.

${ }^{12}$ Ibid., page 183

${ }^{13}$ Metcalf Gilbert, A Green Employment Tax Swap, The Brokkings Institution, Washington 2007.
} 


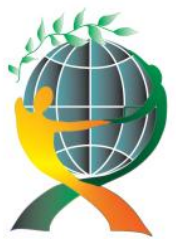

\author{
(online) $=$ ISSN $2285-3642$ \\ ISSN-L = $2285-3642$ \\ Journal of Economic Development, Environment and People \\ Volume 1, Issue 2, 2012 \\ URL: http://jedep.spiruharet.ro \\ e-mail: office jedep@spiruharet.ro
}

Foundation analyzed four areas in which these taxes have been introduced or are seriously considering of introducing them. ${ }^{14}$ These were the areas of energy and water supply, transport and waste in households. The purpose of the analysis was the consideration of ways in which the negative impact of taxes on the poorer segments of the population could be neutralized.

The survey confirmed that, if general terms and conditions remain unchanged, environmental taxes in these areas would have a significant negative impact on poorer households. Population with low incomes, tends to conserve energy, maybe even to the detriment of their own health, especially when it comes to heating. ${ }^{15}$

All proposed strategies are complexed, which means that it is not easy to achieve the ambitious goal of harmonization of taxation of emissions and simplicity in use of taxation, while protecting the poor. It seems that so far no country has engaged in an extensive review of taxation effects of greenhouse gas emissions, and it is certainly necessary because virtually all the individual taxes have only indirect effects.

But unlike taxes on emissions, they do not make the income tax for the government, but instead create new large costs that must be covered and thereby contribute to inflation; in addition, changes in oil and natural gas prices can not be reliably predicted. There is also the danger that it can lead to the return to the use of coal. This means that tax emissions are surely needed, but developments in world energy markets will inevitably affect the areas in which it will be needed and how much, as well as how much will be in the form of incentives rather than punishment.

\title{
5. Limitation of Emissions
}

Limiting emissions has supporters and opponents. Those who support it are attracted to its apparent simplicity, the general character and radicality. To each citizen it would be designated the amount of annual emissions in the energy consumption in households and to travel, including travel by plane. This amount would be the same for all adults, and somewhat less for children. Its respect would be a liability. Here, the crucial role has the government, because it would not only determine the level of quotas, but would also control their use.

Allowed amount of emissions of gases each year would be reduced to a predetermined percentage, in accordance with the realization of national goals to reduce these emissions. Individuals whose lifestyle involves small emissions could sell their surplus of emission at market prices to those whose power consumption means more emissions. In principle, this might include the companies and organizations,

\footnotetext{
${ }^{14}$ Ekins Paul, Dresner Simon, Green Taxes and Charges, Rowntree Foundation, York 2004.

${ }^{15}$ Giddens Anthony, The Politics of Climate Change, Polity Press Ltd, Cambridge, 2009, page 185.
} 


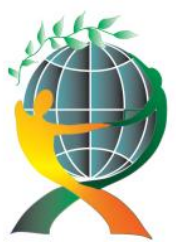

\author{
(online) $=$ ISSN $2285-3642$ \\ ISSN-L = $2285-3642$ \\ Journal of Economic Development, Environment and People \\ Volume 1, Issue 2, 2012 \\ URL: http://jedep.spiruharet.ro \\ e-mail: office jedep@spiruharet.ro
}

not just individuals. Allowed emission amount would be divided into carbon units. Anyone would get "smart" card to the annual allowable amount of emissions which would make redundant many of the specific government programs to encourage savings and people could decide themselves how to use their quotas.

Three different versions are suggested-exchangeable energy quotas, quotas exchangeable for households and personal carbon quotas. The proposer of the first is David Fleming. ${ }^{16}$ It would also relate to the organizations (including government) and individuals. The upper limit of emissions would be determined in accordance with the objectives of reducing emissions at the country level. The plan would include in the oil, natural gas, electricity and coal. Individuals would be able to sell their units immediately upon their acquisition, and, if necessary, to re-buy them in the market.

Roberts and Thumin ${ }^{17}$ emphasized that the introduction of restrictions on emissions will directly make it easier for people to change their behavior. It is possible that it will motivate them to action, but it will not be provided to them. Limiting emissions can not, therefore, be a substitute for other measures necessary to curb emissions of gases that produce greenhouse gases. Roberts and Thumin have done what they believed to be missing - they gave a detailed analysis of the arguments for and against this approaches.

Suggestions to limit emissions of these gases is not possible to test with the pilot survey. The main reason for this is for that to function, the program had to be forcibly put into practice. Roberts and Thumin do not perform any strong conclusions, but based on their observations, there is the standpoint that the limitation of emissions is impractical and unworkable. When this whole idea is carefully considered, its apparent advantages disappear.

\title{
6. Conclusion
}

None of the approaches that is based mainly on the deprivation will not succeed. We must create a positive model of low carbon future that will, in addition, be consistent with the current everyday life of common man. Such model does not currently exist and we need to find it. There has to be a vision emerged from the political, social and economic contemplation. It can not be utopia, but it will have features of utopian ideals which should be pursued. It is necessary to achieve a mix of idealism and persistence. For

\footnotetext{
${ }^{16}$ Fleming David, Energy and the Common Purpose, Lean Economy Conncetion, London, 2006.

${ }^{17}$ Roberts Simon, Thumin Joshua, A Rough Guide to Individual Carbon Trading, Centre for Sustainable Energy, London 2006, page 3 .
} 


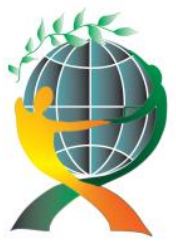

\author{
(online) $=$ ISSN $2285-3642$ \\ ISSN-L = $2285-3642$ \\ Journal of Economic Development, Environment and People \\ Volume 1, Issue 2, 2012 \\ URL: http://jedep.spiruharet.ro \\ e-mail: office jedep@spiruharet.ro
}

example, lifestyle changes that contribute to the reduction of greenhouse gas emissions will directly affect the economy. If they are due to create greater employment opportunities, than currently available, they will have a direct and pragmatic value.

To achieve these goals it will be necessary to establish vigorous management of companies, NGOs and citizens, who will also need to create new forms of joint action and cooperation and, where the situation requires so, to fully use modern communication network. Governments need to set themselves ambitious goals. For example, in finding new ideas and technologies can create competition that would include recognition and awards for outstanding achievements.

Some measures will have to be very harsh, many will be unpopular and will trigger to resistance. On the path of reforms often stand powerful interests and they must reach a compromise. The attitude of many authors is that even very severe restrictions, if they are properly approached, can create new possibilities and in practice it almost always happens. In response to climate change and ensuring energy security, we can expect a large number of technological innovations and should do our best to encourage this processes. Without such innovation is not possible to imagine the end of our dependence on oil, natural gas and coal which are the main sources of environmental pollution. The transition to renewable energy sources is essential and must be very extensive. But research shows that the penetration process of technological change in the overall economy and society could take years. For the problems we face there are no quick solutions-what is forthcoming, is hard work, and even with significant breakthroughs that we accomplish and that we really need.

But the reward is exceptional. Ahead of us is a completely different world, if we can find the way to it. The world in which not only that climate change is curbed, but where there is no more oil domination in world politics.

Finally, we could finish with some selected proposals by Anthony Giddens, in his book The Politics of Climate Change, which are extensively used in research of this paper: $:^{18}$

1. Strive for political and economic convergence, whenever possible, and do it actively. It is important to create the vanguard of entrepreneurs, that will draw the maximum benefit from the economic benefits of professionally guided environmental policy. Fear and anxiety are not always effective motivators, especially when the risks are abstract and threats are distant. In addition, the risks of climate change, how the public perceives them, are just one of many concerns.

\footnotetext{
${ }^{18}$ Giddens Anthony, The Politics of Climate Change, Polity Press Ltd, Cambridge, 2009, pages 1-22.
} 


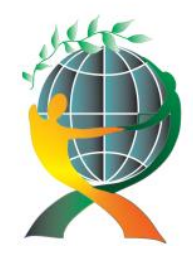

\author{
(online) $=$ ISSN $2285-3642$ \\ ISSN-L = 2285 - 3642 \\ Journal of Economic Development, Environment and People \\ Volume 1, Issue 2, 2012 \\ URL: http://jedep.spiruharet.ro \\ e-mail: office jedep@spiruharet.ro
}

2. Try to introduce care about climate change in the daily lives of people, although it is very hard to do so. Sometimes the best way is indirect. The public would likely respond rather to the initiative to save energy, than to the warnings of the dangers of climate change. It should not discuss much about goals. What is important at this point is how to determine policy on climate change. Setting goals can serve as an excuse for inaction, rather than the other way around. Taxation of emissions is a good thing, but those taxes must not be introduced individually. It is necessary to make a complete review of the tax system.

3. To establish accurate procedures for assessing long-term nature of risk, because the policy in terms of climate change, involves complex measures. We must create a future where the majority of energy needs to be supplied from renewable energy sources. It will be a truly far-reaching transition, with an abundance of complex social and economic consequences. Intensive and constantly cooperation with other countries, regions and cities in the broader global network. Adding to its politics some utopian thinking, since in any scenario, we are going towards a society that will ultimately be quite different from today's. We have to take a chance.

\title{
7. References
}

[1] Ekins Paul, Dresner Simon, Green Taxes and Charges, Rowntree Foundation, York 2004.

[2] Ellerman Denny et al., Markets for Clean Air, Cambridge University Press, Cambridge 2000.

[3] European Commision: Adapting to Climate Change in Europe, Commission of the European Communities, Brussels 2007.

[4] Fleming David, Energy and the Common Purpose, Lean Economy Conncetion, London, 2006.

[5] Giddens Anthony, The Politics of Climate Change, Polity Press Ltd, Cambridge, 2009

[6] Grandov Z.: International Economics and Globalization, BTO, Belgrade, 2009.

[7] Gwyn Prins, Steve Raynor, The Wrong Trousers, James Martin Institute, Oxford 2007

[8] MacKenzie Donald, Making Things the Same, School of Social and Political Studies, Edinburgh 2008

[9] MacKenzie, Donald "Constructing Emissions Markets" in the book Material Markets, Oxford University Press, Oxford 2009, chapter 7.

[10] Metcalf Gilbert, A Green Employment Tax Swap, The Brokkings Institution, Washington 2007.

[11] Roberts Simon, Thumin Joshua, A Rough Guide to Individual Carbon Trading, centre for Sustainable Energy, London 2006

[12] Slović Dragoslav, Epigrams, Fineks, Belgrade, 2011.

[13] Stern Nicholas, „Key Elements of a Global Deal on Climate Change“, 2008. Available on the internet site of London 


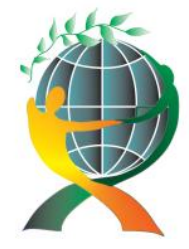

\author{
(online) $=$ ISSN $2285-3642$ \\ ISSN-L = 2285 - 3642 \\ Journal of Economic Development, Environment and People \\ Volume 1, Issue 2, 2012
}

URL: http://jedep.spiruharet.ro

e-mail: office jedep@spiruharet.ro

School of Economics.

[14] Vidaković S.: Financial due dilligence of Companies, Novi Sad, 2007. 